\title{
A DE FACTO ADOPTION DOCTRINE FOR SOUTH AFRICA?
}

\author{
Anne S Louw \\ $B A$ Bluris LLB LLD \\ Associate Professor, Department of Private Law \\ University of Pretoria
}

\section{SUMMARY}

Despite this seemingly bright-line distinction between adopted and non-adopted children, the South African courts have in recent times shown an increased willingness to grant de facto adopted children some, if not all, the rights reserved for formally adopted children. The approach adopted by the judiciary in such cases has raised the question of whether, or to what extent, a doctrine of de facto adoption has been created in South Africa. If such a doctrine is found to exist, it would imply that the judiciary is increasingly inclined to treat de facto and de jure adopted children alike. The article investigates the various contexts within and the extent to which the courts have been willing to recognise de facto adoptions. Based on the trends apparent from the judgments in question, the article concludes that a doctrine of de facto adoption has evidently been created in the context of finding a duty of support. The application of such a doctrine in the context of customary law, adoptions and baby-swop cases are for different reasons found to be inappropriate, while the extension of such a doctrine on a case-by-case basis to find a right to intestate succession is regarded as worth considering and pursuing.

\section{INTRODUCTION}

Although widely accepted in the ancient civilisations of Rome and Greece, adoption had no common law authority in South Africa ${ }^{1}$ as in many other countries, including England, ${ }^{2}$ Canada, ${ }^{3}$ and the United States. ${ }^{4}$ Legislation therefore, had to be enacted to provide an avenue for transferring parental responsibilities and rights to strangers in law. All statutory adoption schemes require the prospective adoptive parent(s) to satisfy a complex array of requirements to ensure that the child is placed with suitable caregivers and

Ferreira Interracial and Intercultural Adoption: A South African Legal Perspective (Unpublished doctoral thesis, UNISA 2009) 19; Van der Walt "The History of the Law of Adoption in South Africa" 201435 Obiter 421430.

2 See Lowe "English Adoption Law: Past, Present, and Future" in Katz, Eekelaar and Maclean (eds) Cross Currents Family Law and Policy in the US and England (2000) 307.

3 Lowe in Katz et al Cross Currents Family Law and Policy in the US and England 308.

4 See eg, Baunach "The Role of Equitable Adoption in a Mistaken Baby Switch" 1992-1993 31 University of Louisville Journal of Family Law 501 503; Robinson "Untangling the 'Loose Threads': Equitable Adoption, Equitable Legitimation, and Inheritance in Extralegal Family Arrangements" 199948 Emory LJ 943954. 
the adoption is in the best interests of the child. ${ }^{5}$ The current worldwide trend is towards more openness in adoption, protecting the right of adopted children to know their origins and in some cases even allowing children to retain links with their natural parents or other significant persons after being adopted. ${ }^{6}$ Despite this trend, an adoption decree usually severs all the legal ties between the adopted child and his or her natural family. ${ }^{7}$

In terms of section 242(3) of the South African Children's Act, ${ }^{8}$ an adopted child must for all purposes be regarded as the child of the adoptive parent and an adoptive parent must for all purposes be regarded as the parent of the adopted child. The adoptive family, therefore, substitutes the natural family for all purposes in law. As far as the insertion of the adopted child into the adoptive family is concerned, a parent has since 1937, when the term was for the first time ${ }^{9}$ defined in South African legislation, ${ }^{10}$ included an adoptive parent. ${ }^{11}$ The current Children's Act, very significantly, defines an adopted child and an adoptive parent, respectively, as a child who has been adopted, or a person who has adopted a child, in terms of "any" law. ${ }^{12}$ It is not certain whether, or to what extent, the legislator contemplated the possible parallel recognition of extra-judicial adoptions in terms of any "other" legal system, such as Islamic ${ }^{13}$ or customary law system. Be that as it

5 Schwenzer "Tensions between Legal, Biological and Social Conceptions of Parentage" 200711 Electronic Journal of Comparative Law 21 http://www.ejcl.org/113/article113-6.pdf.

6 See Katz "Dual Systems of Adoption in the United States" in Katz et al Cross Currents Family Law and Policy in the US and England 305; Lowe in Katz et al Cross Currents Family Law and Policy in the US and England 327-329. The South African Children's Act 38 of 2005 (s 248) allows an adopted child, an adoptive parent and a biological parent of an adopted child access to the information contained in the adoption register after the child has reached the age of 18 years subject to certain conditions. A parent or guardian of a child may enter into a post-adoption agreement with prospective adoptive parent to make provision for continued communication and provision of information after the adoption order has been granted (s 234).

7 Schwenzer 200711 Electronic Journal of Comparative Law 21.

838 of 2005. Any reference to the Children's Act in this article has this Act in mind unless specifically indicated otherwise.

9 The only pre-union Act found to contain any indication of the meaning of "parent" is the Children's Protection Act 38 of 1901 (Natal). In s 33 of this Act it was stated that for purposes of interpreting the provisions in the Act relating to the guardianship and maintenance of children found to be destitute in terms of the Act, the word "parent" included a stepparent. The said provisions obliged the "parents" of such children to contribute towards their maintenance while being maintained by the Government or in a Government institution. This broad definition of "parent", therefore, seems to have been purely functional from a financial point of view and was obviously not meant to apply in general. The first post-union Children's Protection Act 25 of 1913 did not define "parent".

10 Children's Act 31 of 1937: S1 sv "parent".

11 See $s 1$ of the Children's Act 33 of 1960, s 1 of the Child Care Act 74 of 1983 and s 1(1) of the Children's Act 38 of 2005 that has replaced all the previous definitions. An adoptive parent is thus for all purposes in law placed in the same position as a biological parent of the child. This fact is reiterated by the provisions contained in s 242 of the Act outlining the effects of an adoption order.

12 S 1(1) sv "adopted child" and "adoptive parent".

13 See Assim and Sloth-Nielsen "Islamic Kafalah as an Alternative Care Option for Children Deprived of a Family Environment" 201414 African Human Rights LJ 322-345 for a discussion of the international recognition of kafalah, the Islam equivalent of a de facto adoption. Kafalah is described as "the provision of alternative care without altering the child's original kinship status because in Islam; the link between an adopted child and his 
may, the chapter regulating adoption in the Children's Act seems to envisage only one type of adoption. In terms of section 228, a child is adopted if the child has been placed in the permanent care of a person in terms of a court order that has the effects contemplated in section 242. Thus, apart from the possible uncertainty created by the insertion of "any law" in the definitional section, a child will generally only acquire the status of an adopted child in South Africa if formally adopted in terms of the procedure outlined in the Children's Act.

Despite this seemingly bright-line distinction between adopted and nonadopted children, the South African courts have in recent times shown an increased willingness to grant de facto adopted children some, if not all, the rights reserved for formally adopted children. The judiciary's readiness to treat de facto and de jure adopted children alike may be commended for achieving fairer results, but may inadvertently have created other inequities and anomalies. Although a common feature in family law cases, ${ }^{14}$ the exercise of discretionary powers in these cases has created uncertainty about the legal status of informally adopted children and their assumed or putative parents. The legal position of stepparents vis-à-vis their stepchildren may be used as a case in point. ${ }^{15}$ The court in $M B V N B^{16}$ held a stepfather liable for the school fees of his stepchild because he acted in loco parentis, akin to an adoptive father. Although this precedent has not been interpreted as necessarily imposing the same burden on all stepparents, it has renewed doubts about the scope of the responsibilities of stepparents vis-à-vis their stepchildren. ${ }^{17}$ While stepparents may incur responsibilities, they generally do not acquire parental rights, for example, the right to retain contact with their stepchild after divorce. The court in Flynn $v$ Farr ${ }^{18}$ furthermore refused to recognise a stepson as a descendant of his stepfather for purposes of the law of intestate succession, despite the fact that the stepfather had acted in loco parentis, treating his stepson for all purposes as his own son during his lifetime.

The stepparent-stepchild relationship will not be the main focus of this article. The article will trace the extent to which the judiciary has given legal recognition to de facto adoptive relationships in South Africa in general. In

biological parents must remain unbroken" (329-330). As far as could be ascertained, the recognition of kafalah has not been the subject of court proceedings in SA.

14 Schneider "The Tension between Rules and Discretion in Family Law: A Report and Reflection" 1993-1994 27 Family Law Quarterly 229 posits that the tension between rules and discretion is "perhaps nowhere more pronounced and more troubling than in Family Law". Schneider specifically refers (229) to the impact of the application of the bestinterests-of-the-child standard in family law proceedings that, in his opinion, has given judges "acres of room to roam".

15 See Mahoney "Stepparents as Third Parties in Relation to their Stepchildren" 2006-2007 40 Family Law Quarterly 81 108, who concludes that while the primacy of biological and adoptive parenthood have been reaffirmed in dealing with the large categories of nontraditional families "[a]t the same time, the boundaries of family have been adjusted, in particular jurisdictions for particular legal purposes, to recognize and regulate stepfamilies".

162010 (3) SA 220 (GSJ).

17 See Van Schalkwyk "'n Stiefkind se Aanspraak op Onderhoud van 'n Stiefouer" 2012 Journal of South African Law $205 \mathrm{ff}$.

182009 (1) SA 584 (C) par 1-2. 
reviewing the case law, attention will be drawn to the different contexts in which de facto adoptions have been recognised as well as the grounds for such recognition. Consideration will also be given to the so-called "doctrine of equitable adoption" applied in the United States, mainly as a means to achieve fairness in the context of intestate succession, but also applied in other contexts, such as baby-swop cases and the duty of support. ${ }^{19} \mathrm{~A}$ critical analysis of the South African judgments will be used to determine whether the discretion exercised by the courts when deciding to recognise a de facto adoptive relationship cannot be placed on a more principled basis. According to Black's Law Dictionary ${ }^{20}$ a "doctrine" is "a principle, esp. a legal principle that is widely adhered to". While not necessarily an authoritative source, Wikipedia ${ }^{21}$ explains the creation of a legal doctrine in the following elucidating terms:

"A doctrine comes about when a judge makes a ruling where a process is outlined and applied and allows for it to be equally applied to like cases. When enough judges make use of the process soon enough, it becomes established as the de facto method of deciding like situations".

With this definition and explanation in mind, the article will investigate whether and to what extent a doctrine of de facto adoption has developed in South African law.

\section{THE RECOGNITION OF DE FACTO ADOPTIONS IN SOUTH AFRICA}

\section{Earliest accounts}

Before the first statute formally regulating the adoption of a child was enacted in South Africa in 1923, the courts generally desisted from attaching any legal consequences to an agreement by biological parents purporting to transfer their parental rights. In Robb $v$ Mealey's Executor ${ }^{23}$ the court refused to allow an "adopted" child to succeed her only surviving adopted parent on intestacy. The girl had been maintained and supported as the only child and daughter of the deceased and his wife while she was still alive. ${ }^{24}$ Describing the case as a "grievously hard" one, De Villiers CJ concluded that since the adopted child was regarded as a stranger to the adopter, she could

\footnotetext{
See in this regard, Van Schalkwyk 2012 Journal of South African Law 205.

8ed (2004).

See https://en.wikipedia.org/wiki/Legal_doctrine.

2 See in general Rubin \& Feeley "Creating Legal Doctrine" 1995-1996 69 Southern California Law Review $1989 \mathrm{ff}$ for an investigation of the process involved in creating new legal doctrine.

23189916 SC 133.

24 Robb v Mealey's Executor supra 134. It was held that - "the law of this Colony does not recognise adoption as a means of creating the legal relationship of parent and child. Under Roman law this relationship was created, but the Dutch law did not, in this respect, follow the Roman law."
} 
not claim a right of succession $a b$ intestato in respect of the adopter's estate. $^{25}$

In the 1907 case of Fibinger $v$ Botha, ${ }^{26}$ the court refused to honour the terms of a private adoption agreement. In this case, Mr and Mrs Botha, the biological parents of the child, had entered into a "deed of adoption" committing their child to the Fibingers' care. The latter couple was given permission to raise the child as their own legitimate child. In addition, the deed gave the adopting parties sole control over the child until she came of age. The biological parents also agreed in terms of the deed "not to interfere with the child, its education or religion, not to take any action for the child's well $^{27}$ or woe without first consulting and obtaining the adopting party's consent". ${ }^{28}$ Describing the deed as "an extraordinarily worded document", the court dismissed the application despite the fact that the adopters purportedly had treated the child well and appeared to have great affection for "it". ${ }^{29}$ The court argued that even if the child was returned it would only be temporary because the application would, in the end, have to be unsuccessful:

"In law, the father is entitled to the custody of the child, but even though the

child has been taken surreptitiously, I cannot regard this as spoliation".

In Edwards $v$ Fleming ${ }^{31}$ a couple attempted to resist the return of a then still called "illegitimate" child to its mother based on a similarly worded private agreement between the parties shortly after the birth of the child. ${ }^{32}$ The court held that the mother, as the right and proper guardian of her "illegitimate" child, had the superior claim "unless her character is such to endanger the welfare of the child". Since there was nothing to support such a flaw in the character of the mother, the court ordered the child to be delivered back to her within ten days from the date of the order. Despite being loathe to do so, the court also made a cost order against the de facto caregivers because it could not overlook the fact that they had been given every opportunity to return the child. As in the case of Fibinger, the court did

Robb v Mealey's Executor supra 134.

(1905-1910) 10 HCG 97.

Sc., weal.

28 Fibinger $v$ Botha supra 98. To make sure the agreement was binding, the biological parents agreed that they would not attempt to recover the child "unless upon the consent of the adopting party and upon paying the sum of $£ 250$ sterling until the child has reached its tenth year, and $£ 500$ sterling from then until its coming of age" (98). When the child was two years and seven months, the biological parents took the child from the adopters under the ruse of going out to buy the child sweets. The adopters' thereupon demanded the return of the child, threatening proceedings on the ground of "spoliation" unless the child was restored.

29 Fibinger $v$ Botha supra 101.

30 Ibid.

31 1909 TH 232.

32 The court in this case was far more dismissive of the application - "it is quite clear that a contract which practically makes a child a chattel cannot be enforced, not necessarily because it is an immoral contract, but because in these cases the welfare of the child is the determining consideration, and because the enforcement of such contracts would create conditions resembling slavery". 
allow the adopters to receive compensation for having looked after the children. ${ }^{33}$

As a legal act, adoption became formally regulated and recognised only in 1923 with the enactment of the Adoption of Children Act ${ }^{34}$ and has been regulated by statute ever since. ${ }^{35}$ In defiance of the provisions of the Adoption Act ${ }^{36}$ applicable at the time, the High Court of Southern Rhodesia in Ex parte Hopwood and Savage ${ }^{37}$ was willing to grant "custody" and guardianship to the de facto caregivers of a child. The caregivers were prevented from formally adopting the child because they were not domiciled within the jurisdiction of the court as required by the applicable Act. While the court initially acknowledged that such an order would probably not be competent under the Act, ${ }^{38}$ Tredgold $\mathrm{J}$ had no doubt that it was "in the best interests of the child that she should be placed in the care of those who have de facto been her parents for a period of years". ${ }^{39}$ It was argued that as upper guardian the court had the power to make any order in "appropriate circumstances" ${ }^{\prime 40}$ which, it was concluded, clearly existed in this case since the child's mother was dead and the father had not taken any interest in the child. ${ }^{41}$

The discussion that follows will focus on similar, more recent cases in which the courts were approached to give legal recognition to a de facto parent-child relationship that resembled an adoptive relationship but had never been formalised in terms of the applicable adoption statute. The cases have been grouped together in the following distinguishable categories: cases decided in the context of customary law, the law of intestate succession, the duty of support, the context of a baby-swop and various other contexts.

33 Although the amount was not specified in Fibinger $v$ Botha supra 100, the parents undertook to compensate the caregivers for all reasonable expenses for the keep and maintenance of their child. In Edwards v Fleming supra 235, the court allowed a sum of 15 pounds for maintenance to be set off against the cost order made against the caregivers.

3425 of 1923.

35 The 1923 Act was repealed and incorporated in the Children's Act 31 of 1937 (Ch VII ss 68-79), followed by the Children's Act 33 of 1960 (Ch VII ss 70-82) and then by the Child Care Act 74 of 1983 (Chapter 4). The provisions contained in Chapter 15 of the Children's Act currently regulate adoption.

36 Children's Protection and Adoption Act Ch 155

$37 \quad 1943$ SR 145

38 The court argued that any rights which the courts may previously have had in approving adoption agreements had been superseded by the Act (Ex parte Hopwood and Savage supra 146).

39 Ex parte Hopwood and Savage supra 146.

40 Ibid.

41 Ex parte Hopwood and Savage supra 147. The court in AD v DW 2008 (3) SA 183 (CC) (Centre for Child Law as Amicus Curiae; Department for Social Development as Intervening Party) par 34 similarly concluded that even though the children's court was (in terms of the then still applicable Child Care Act 74 of 1983) the forum most conducive to protecting the best interests of the child in cases of adoption, the jurisdiction of the high court could not be "ousted" as a matter of law. However, unlike Tredgold $\mathrm{J}$ in the Hopwood case, Sachs $\mathrm{J}$ in $A D$ did not find the case to be "one of those very exceptional cases where bypassing the Children's Court procedure could have been justified" (par 34). 


\section{Recognition of de facto adoptions in terms of customary law}

In Kewana $v$ Santam Insurance Co $L t d^{42}$ the Transkei Appellate Division had to decide whether to uphold a decision that a child adopted in terms of customary law was not entitled to compensation for loss of support resulting from the negligent killing of the adoptive parent in terms of the Transkei Compulsory Motor Vehicle Insurance Act. ${ }^{43}$ In this case, a traditional adoption ceremony was held. A sheep and a goat were slaughtered for the occasion "to give the occasion the significance and solemnity of an act being done in accordance with tribal customs". ${ }^{44}$

The court rejected the view that because the child was not adopted in terms of the statutory procedure there was any duty of support: ${ }^{45}$

"It was held that, because the child was not adopted under the Children's Act 33 of 1960, there was no duty of support. This Act, however, does not modify or repeal the customary law of adoption. Adoption, which played a great role in Roman law, was obsolete in Roman-Dutch law. It was first introduced by the Adoption of Children's Act 1923 (see Hahlo and Kahn -The Law of South Africa: The Development of its Laws and Constitution 358). This legislation therefore, introduced a right which did not exist. It filled a vacuum in the common law, but there is no basis for holding that it also modified or replaced adoption under customary law which remains enforceable under s 53 of the Constitution [Transkei Constitution Act 1976] while adoption under the Children's Act is governed by the provisions of that Act. It cannot be said that only an adoption under the Children's Act is recognized in Transkei. A child adopted according to the law of any other country, say England or Germany, would not be precluded from enforcing a right to be maintained by his adoptive parent in Transkei."

421993 (4) SA 771 (TkA).

4325 of 1977.

44 Kewana $v$ Santam Insurance Co Ltd supra 773A. In order to determine whether the deceased was under a legal duty to maintain the child, the court had to determine whether the ceremony described by the appellant was an adoption and whether such adoption is part of customary law, particularly because the adoptive parent was a woman (773A-B). There was some contradictory evidence from the expert witnesses as to the possibility of a woman adopting a child in terms of the customs in Transkei (773D-774F). However, upon ascertaining that the adoptive mother did not adopt the boy for benefit to herself or only to maintain him, the court accepted that she assumed full responsibility for him during her lifetime $(774 \mathrm{H})$. Allegations to the effect that the relationship was one of fostering were dismissed (774I).

45 Kewana v Santam Insurance Co Ltd supra 776C-D.

46 Olmesdahl in South African Human Rights Yearbook (1994) 23 at the time welcomed the decision as a long-overdue recognition of the social reality of relationships created by customary law, adding that "for many years customary spouses and children have suffered under a rigid application of the technicalities of Roman-Dutch Law". The remark by Olmesdahl seems strange considering the fact that adoption in SA has always had to be regulated by statute because the Roman law of adoption was not received in Roman-Dutch law. It is, therefore difficult to see how the rigid application of Roman-Dutch law could have contributed to the suffering of children: See Kewana $v$ Santam Insurance Co Ltd supra 776B; Joubert "Aspekte van die Aanneming van Kinders" 198316 De Jure 129 130-131. The decision was in line with the view expressed by Maithufi that customary law adoptions should be regarded as valid despite the absence of a court order: See South African Law Commission Discussion Paper 103 on the Review of the Child Care Act Project 110 (23 December 2001) par 18.3.12. 
In Thibela $v$ Minister van Wet en Orde ${ }^{47}$ the court considered an agreement in terms of which a husband paid lobola for his wife and her "illegitimate" son sufficient to create a duty of support between the husband and the "illegitimate" son in terms of Pedi custom. "Expert evidence attested to the fact that such payment would result in the child becoming a "child" of the husband. ${ }^{49}$ The court consequently held that the damages suffered by the child arising from the death of his deceased "father", who could no longer fulfil his duty of supporting him, must be included in the mother's claim for damages.

As in the Kewana-case ${ }^{51}$ the court in Metiso $v$ Padongelukkefonds ${ }^{52}$ was, called upon to decide whether a customary law adoption was valid and thus created a legally recognisable duty of support for purposes of a claim against the Road Accident Fund. The court ${ }^{53}$ held that the customary law adoption should in the interest of the children be considered valid despite its possible lack of publication as prescribed by custom. The court ${ }^{54}$ concluded that the deceased's promise to care for the children, even if not a completed adoption in terms of customary law, was sufficient to create a legally recognisable duty of support towards the children - if not in terms of the common law then a logical extension thereof. ${ }^{55}$ Bertelsmann $\mathrm{J}^{56}$ argued that to deny the legality of such an undertaking would be contrary to -

"the new ethos of tolerance, pluralism and religious freedom which had consolidated itself in the community even before the formal adoption of the interim Constitution on 22 December 1993".

In a special review referred to the South Gauteng High Court by the magistrate in Maneli $v$ Maneli, ${ }^{58}$ the court had to determine whether the magistrate was correct in her conclusion that the respondent had a legal duty to maintain his child adopted by the respondent and his wife in terms of

1995 (3) SA 147 (T).

Thibela v Minister van Wet en Orde supra 150E-F.

49 Thibela $v$ Minister van Wet en Orde supra 150B. For a discussion of the possible conflict between the consequences of the payment of isondlo under customary law and the acquisition of parental responsibilities and rights by the unmarried father in terms of $s 21$ of the Children's Act, see Louw The Acquisition of Parental Responsibilities and Rights (Unpublished doctoral thesis UP 2009) 128-129.

Thibela v Minister van Wet en Orde supra 150G.

Kewana $v$ Santam Insurance Co Ltd supra.

2001 (3) SA 1142 (T).

Metiso v Padongelukkefonds supra 1150C-D.

Metiso v Padongelukkefonds supra $1150 \mathrm{H}$.

55 Metiso $v$ Padongelukkefonds supra 1150I. In a certain sense the undertaking could perhaps be compared to what may be called a putative adoption, where the caretakers bona fide assume parental responsibilities and rights in a manner befitting adoptive parents while being unaware of the fact that the "adoption" has not in fact created the said responsibilities and rights (and is consequently void and without legal effect). Under these circumstances, the de facto caregivers are often referred to as the putative parents of the child in literature.

Metiso v Padongelukkefonds supra 1150E.

57 Referring to Amod v Multilateral Motor Vehicle Accidents Fund (Commission for Gender Equality Intervening) 1999 (4) SA 1319 (SCA) 328B.

582010 (7) BCLR 703 (GSJ). 
customary law. The applicant and the respondent had married in community of property after first having concluded a customary law marriage. ${ }^{59}$ At the instance of the respondent, they decided to adopt an orphaned baby girl in terms of Xhosa customary law. After the performance of Xhosa traditional rites and rituals, the baby was taken into the parties' home and the girl, who was 12 years old at the time of the application, was in all respects regarded and treated as the child of the parties. Pursuant to the customary law adoption, the parties approached the Department of Home Affairs where they registered and named the child "as their own child". ${ }^{60}$ The bond that had developed between the child and the respondent had endured despite the breakdown of the parties' marital relationship. ${ }^{61}$ Following a maintenance complaint against the respondent in terms of section 10 of the Maintenance $\mathrm{Act}^{62}{ }^{62}$ the magistrate held an enquiry and found that the respondent had a duty to maintain the child despite not having adopted the child formally in terms of the Child Care Act ${ }^{63}$ or the Children's Act. ${ }^{64}$ In its deliberations, the high court focused mainly on the constitutional imperative to develop customary law and the common law. ${ }^{65}$ In so doing, the court held:

"The respondent's legal obligation to support the adopted minor child as a consequence of the development of common law is not contrary to public policy, bonis mores, the principles of natural justice or the spirit, purport and objects of the Bill of Rights. The Child Care Act, the Maintenance Act, or the

Children's Act do not repeal or modify Xhosa customary law of adoption."

Mokgoathleng $\mathrm{J}$ thought that developing the common law to recognise a duty of support between a parent and a child adopted in terms of customary

59 Maneli v Maneli supra par 2.

60 Maneli v Maneli supra par 6.

61 Maneli $v$ Maneli supra par 7.

6299 of 1998.

637 of 1983.

Maneli v Maneli supra par 8-9.

65 The judgment initially seems to imply that formal adoptions are effected in terms of the common law. The following observations from the judgment clearly reflect this misconception, in addition to containing other inaccurate information: "Under the common law, a judicial act is required in order to effect an adoption. Xhosa customary law of adoption is not in conflict with The Bill of Rights or s 18(1)(a) Child Care Act 74 of 1983 and s 23 and 25 of the Children's Act No 38 of 2005, decree that adoption or guardianship must be effected by an order of the Children's Court" (Maneli v Maneli supra par 19), and further down "consequently a minor child adopted in terms of Xhosa customary law should be deemed to be legally adopted in terms of the common law and The Constitution of the Republic of South Africa" (Maneli v Maneli supra par 22). The reference to ss 23 and 25 is inaccurate since s 23 concerns application for care and/or contact and only mentions adoption in the context of a simultaneous application for care and/or contact and an application to adopt while s 25 directs the courts to regard an application for guardianship by non-South African citizens as an intercountry adoption. The implication in the first observation to the effect that a children's court can grant an order for guardianship is inaccurate since only the high court has jurisdiction to grant an order relating to the guardianship of a child (s 45(3)). Roman-Dutch law did not allow the transfer of parental power to another by means of an adoption: See Van der Walt 201435 Obiter 429. As indicated above, adoption was introduced via legislation and has thus always been regulated by statutory law. The common law regulates the duty of support between parent and child - not between adoptive parent and adopted child.

66 Maneli v Maneli supra par 30. 
law would improve the effectiveness of the application of the maintenance system as it would encourage and allow a huge number of people living under customary law to enforce the legal rights to maintenance. ${ }^{67}$ The court reasoned, "[f]or the minor child's dignity, sense of identity and psychological well-being, it is preferable if it grows up in the social milieu from which it originates" and -

"[t]he minor child's long-term emotional and psychological well-being is of paramount importance in circumstances where a customary law adoptive parent unlawfully relays [sic delays] to carry out its parental duties and obligations."

The conclusion reached by the magistrate that the customary law adoption created a legally enforceable duty of support was thus deemed to be in accordance with the precepts of justice and the court consequently ordered the magistrate to determine the amount of maintenance to be contributed by the respondent. ${ }^{69}$ More important for purposes of this discussion, however, is the additional order directing the Director-General of the Department of Home Affairs to register the child as the adopted child of the parties in terms of the Births and Deaths Registration Act. ${ }^{70}$ This order thus effectively equated the status of a child adopted in terms Xhosa law with a child adopted in terms of the Children's Act. The order is significant because it is wholly unprecedented in our law. While customary law adoptions have been recognised for purposes of creating a legally enforceable duty of support in the past, such adoptions have never before been recognised in express terms as having the same legal effect as formal adoptions.

\section{Recognition of de facto adoptions for purposes of intestate succession}

It is interesting to note that in terms of section 8(1) of the first South African Adoption Act of 1923, an adopted child did not acquire any right -

"devolving on the heirs ab intestato of any child of lawful wedlock of the adopting parent or become entitled to any succession (whether by will or $a b$ intestato) jure representationis his adopting parent unless a contrary intention clearly appeared from the instrument".

Section 71(2) of the Children Act of $1937^{71}$ also terminated the legal bond between a child and his natural parents "except the right of the child to

\footnotetext{
Maneli v Maneli supra par 38.

Maneli v Maneli supra par 41.

Maneli v Maneli supra par 44.

51 of 1992 . The judgment (par 45) mistakenly directed the Director-General to register the adoption in terms of s2 of the said Act. S 2 merely provides for the scope of the application of the Act, i.e. to SA citizens and non-citizens who sojourn temporarily or permanently in the Republic for whatever reason. The reference should presumably have been to s3 which places the administration of the Act in the charge of the Director-General of Home Affairs and/or s7 providing inter alia for the rectification of particulars, more specifically s7(2).

7131 of 1937.
} 
inherit from them ab intestato". The Children Act of $1960^{72}$ contained a similar provision. The complete severance of all ties ${ }^{73}$ between the adopted child and his or her natural family was only brought about in South Africa by the enactment of section 20(2) of the Child Care Act of $1983 .{ }^{74}$

The court in Flynn v Farr, ${ }^{75}$ as already indicated, refused to declare Flynn, the de facto adopted son of his stepfather, Farr, a descendant of the latter for purposes of section 1(1)(b) of the Intestate Succession Act. ${ }^{76}$ The executrix of the estate of the late Flynn sought relief in various alternative forms, including an application for a general order declaring the words "adopted child" in the Intestate Succession $\mathrm{Act}^{77}$ to be interpreted to include both de lege and de facto adopted children, a general order to declare the definition in the said Act unconstitutional and to amend the definition to include both forms of "adoption"78 and a specific order declaring Flynn a descendant of Farr with a declaration that Flynn inherits the intestate estate of Farr. ${ }^{79}$

In terms of section 1(4)(e) of the Intestate Succession Act, ${ }^{80}$ an adopted child shall be deemed to be a descendant of his adoptive parent or parents and not his natural parent or parents. ${ }^{81}$ Based on this provision, read with the provisions of then still applicable Child Care $A c t^{82}$ to the effect that an adopted child is for all purposes whatever deemed to be the legitimate child of the adopted parent, the court ${ }^{83}$ found that the Intestate Succession Act ${ }^{84}$ made no provision for de facto adoptions. ${ }^{85}$ Before coming to this conclusion, Davis ${ }^{86}$ considered the constitutionality of the differentiation between factually adopted children and legally adopted children as far as their right to inherit intestate was concerned. The court held ${ }^{87}$ that since the differentiation was not based on a listed ground mentioned in section 9(3) of the Constitution, it could not be presumed to be unfair. As a result, the issue was whether the differentiation could be said to unreasonably impair the human dignity of Flynn, the person affected by this differentiation. ${ }^{88}$

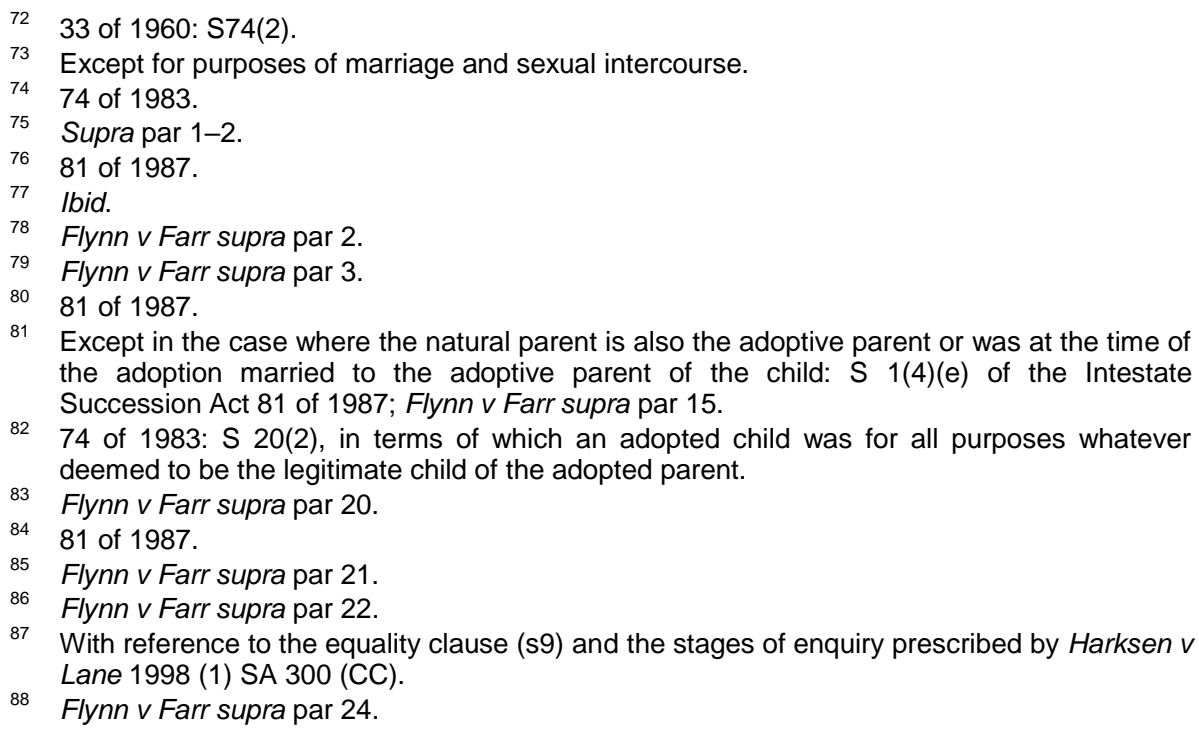


Following indications from a letter to his attorney that supported a conclusion that the legal treatment of Flynn had a negative impact on him, ${ }^{89}$ the court nevertheless proceeded to consider the second question, i.e. whether, on the assumption that the differentiation is discrimination, it is fair discrimination. ${ }^{90}$ In this regard, the court considered the impact that the discrimination may have had on Flynn and the question whether there is a rational reason for allowing de lege adopted children to inherit and not extending the same benefits to de facto adopted children. ${ }^{91}$ Seeking to support the argument that there was no rational reason to deny the same benefits to de facto adopted children, the applicant referred the court to the judgment in Daniels $v$ Campbell. ${ }^{92}$ In that case, the Constitutional Court was prepared to extend the interpretation of "spouse" to include a de facto husband or wife married in accordance with Muslim rites ${ }^{93}$ for purposes of the same section of the Intestate Succession Act.

The respondents, however, argued that the legislator's purpose in differentiating between adopted children and stepchildren was not arbitrary or irrational. ${ }^{95}$ The purpose of the differentiation, in their view, "was directed at bringing certainty and predictability to the law of intestate succession". ${ }^{96}$ The court was referred to the "multiple" difficulties that are avoided by limiting the definition of child in the Act. ${ }^{97}$ Reference was made to a judgment in British Columbia by the Alberta Court of Queen's Bench ${ }^{98}$ in which the court found that the failure of the relevant legislation to recognise de facto adoptees did not violate "essential human dignity and freedom through the imposition of disadvantage, stereotyping, or political or social prejudice". ${ }^{99}$ The respondents argued, "a person always had the option of adopting a stepchild should he or she so desire". ${ }^{100}$ Furthermore, the hurdle created by the other biological parent refusing to consent to the adoption could be overcome by dispensing with the consent of that parent as provided

Flynn v Farr supra par 26.

Flynn v Farr supra par 26.

Flynn v Farr supra par 28.

2004 (5) SA 331 (CC).

Daniels v Campbell supra par 109.

81 of 1987: S1.

Flynn v Farr supra par 35.

Ibid.

97 Flynn v Farr supra par 36. The uncertainties that could arise include the following: What would the minimum length of time be during which the person concerned would have had to act as stepparent? Would all the stepchildren have rights upon intestacy of the stepparent?; What would the position be where a child's natural parents had had multiple marriages? Would a stepchild retain entitlement to claim under the intestacy of his or her natural and substitute parent? If so, this would allow for multiple rights of inheritance known as "double dipping" with clearly unsatisfactory consequences.

98 McNeil v Mac Dougal 1999 ABQB 945 (CanLII) ([2000]) 256 AR 289; [2000] 2 WWR 729 72 CRR (2d) 321; (1999) 74 Alta LR (3d) 359, as discussed in Flynn v Farr supra par 36.

99 Flynn v Farr supra par 36.

100 Flynn v Farr supra par 37. 
for in the Children's Act ${ }^{101}$ and, finally, a stepparent wishing to benefit a stepchild could always to do so by making a will.

Davis $\mathrm{J}^{103}$ found the analogous support of the approach articulated by the respondents in the approach adopted by the majority of the Constitutional Court in Volks NO $v$ Robinson. ${ }^{104}$ In Volks, ${ }^{105}$ a heterosexual couple had lived in a permanent life partnership despite the fact that "there was no legal obstacle to their marriage". "106 Following the death of her partner, Robinson applied for an order declaring her to qualify as a "surviving spouse" for purposes of the Maintenance of Surviving Spouses Act. ${ }^{107}$ The Constitutional Court in Volks ${ }^{108}$ dismissed the application, arguing that there was a fundamental difference between the position of surviving life-partners and surviving spouses. Of special importance to Davis $\mathrm{J}^{109}$ was the fact that the Constitutional Court in Volks found that the provisions of the Maintenance of Surviving Spouses $\mathrm{Act}^{110}$ did not amount to an infringement of Mrs Robinson's right to dignity: ${ }^{11}$

"On the evidence, there is no sustainable legal basis by which to conclude that Mrs Robinson's dignity, in that case, was offended any less than that of Flynn. Therefore, the central holding of Volks, supra, must be applicable in the present dispute."

The court in Flynn ${ }^{113}$ declined to consider the possibility of making a finding of an "equitable adoption" in accordance with a judgment by the High Court of American Samoa, ${ }^{114}$ as proposed by the applicant. According to the headnote to the report of this case -

"an equitable adoption exists when a child has 'stood from an age of tender years in the position exactly equivalent to a formally adopted child'. The Court went on to find, from the evidence as set out, that, in its view, there was more than sufficient evidence to infer that the deceased intended Ato to become his son. The fact that he never actually went as far as to legally adopt Ato was of

101 Flynn v Farr supra par 38.

102 Ibid.

103 Flynn v Farr supra par 43.

1042005 (5) BCLR 446 (CC).

105 Flynn v Farr supra par 3-11.

106 Flynn v Farr supra par 39.

10727 of 1990.

108 Volks NO v Robinson supra par 60.

109 Flynn v Farr supra par 41.

11027 of 1990.

111 Volks NO v Robinson supra par 62, quoted by Davis J in Flynn v Farr supra par 41.

112 According to Brassey $\mathrm{J}$, the passages relating to Volks in the Flynn judgment did tend to suggest that a de facto relationship should not be given legal recognition where nothing prevents the creation of its de jure equivalent. However, as correctly pointed out by Brassey in the $M B$ (par 25) case, the decision in Volks partly contradicted the same court's judgment in Daniels in which the court had recognised a de facto (Muslim) marriage as enough to make the parties "spouses" within the contemplation of the very statute with which Flynn was concerned.

113 Flynn v Farr supra par 51.

114 Estate of Tuinanau Fuinaono (deceased) PR Nos 13-86 and 23-86, discussed in Flynn $v$ Farr supra par 44, described by Brassey $J$ in $M B \vee N B$ supra par 23 as a case "that a remarkably resourceful counsel had contrived to unearth". 
no consequence to the inheritance by Ato of the estate from his late father by way of intestacy".

Despite the similarity of the factual scenario and applicable logic adopted in the Samoan case, Davis $\mathrm{J}$ considered the question of considering foreign law as mandated by section $39(1)$ (c) of the Constitution a related argument "[t]hat in turn, compels an examination of the evidence and the concomitant need for such an approach". 115 The Samoa judgment could not hold sway because there was "also the compelling precedent from British Columbia which goes the other way". ${ }^{116}$ To this Davis $\mathrm{J}$ later added that even if the court was willing to take more seriously the American Samoa case, "for reasons which were never advanced cogently, the evidence, as put up to justify any differentiation that is shown to exist, is sufficient to justify the conclusion that s 9 of the Constitution cannot be applied in this case".

Davis $\mathrm{J}$ concluded with reference to an affidavit by the Chief Director of the National Department of Social Development (DSD) ${ }^{118}$ that the differentiation between de facto and de jure adopted children had a rational basis. ${ }^{119}$ The basis of the arguments put forward by the DSD can be summarised as follows ${ }^{120}$

"if the law were to equate the two relationships for all purposes, the rights of the natural parent might potentially be compromised, the protections against child exploitation provided by the statutory procedures governing de jure adoptions might be by-passed, and the value of certainty implicit in the current system of formal recognition would be undermined".

\section{Davis $\mathrm{J}$ concluded with this afterthought:}

"I am not insensitive to the sadness of this particular case. Unquestionably, the three central parties in this dispute lived happily together, but hard cases make bad law and that must surely be the case in a constitutional dispute where, as in the present case, the implications go further than simply an individual dispute based upon the present legal dispensation."

It is interesting to note that the definition of "descendant" for purposes of the Reform of Customary Law of Succession and Regulation of Related Matters Act ${ }^{122}$ has since been amended. For purposes of this Act, a descendant now includes "a person ... who, during the lifetime of the deceased person, was accepted by the deceased person in accordance with customary law as his or her own child".

\footnotetext{
Flynn v Farr supra par 45.

Flynn v Farr supra par 51.

Ibid.

Flynn v Farr supra par 46 and 47.

Ibid.

See MB v NB supra par 22

121 Flynn v Farr supra par 50.

12211 of 2009, which came into operation on 20 September 2010.
} 


\section{Recognition of de facto adoptions for purposes of duty of support}

Cases in which customary law adoptions have been recognised to found a legal duty of support for purposes of a claim for compensation resulting from the death of the breadwinner or against an estranged parent have already been discussed in paragraph 23 above. Outside the customary law setting, the courts have shown an equal readiness to impute the creation of a duty of support from a de facto caregiving arrangement.

In $M B \vee N B$ a widow with a teenage son married a man who developed a particularly close bond with her son. ${ }^{123}$ Although her husband agreed to adopt the boy, the adoption was never pursued. The boy did however, formally take his stepfather's surname. The stepfather agreed with the boy's mother that he should enrol in a private school and they completed and signed, as father and mother, the application forms for the boy's admission to the school as a boarder. ${ }^{124}$ The application was successful. The marital relationship between the parties subsequently came to end as a result of the husband's adulterous relationship(s). ${ }^{125}$ During the divorce proceedings that followed the plaintiff sought to hold the defendant liable for the boy's not inconsiderable school fees, based on his formal undertaking to assume joint liability. ${ }^{126}$ As the stepfather of the boy, the defendant denied any and all liability for the support of the boy, including a contribution towards the school fees to which he had agreed. The court rejected the alleged contractual basis of the claim but found liability on another ground. Without referring to estoppel by name, the court held that by agreeing to give the boy his name, the defendant impliedly represented to the boy himself, to the plaintiff and to the world at large that he proposed to stand in relation to the boy as a father to a son. ${ }^{127}$ The court argued that during the course of the marriage the defendant discharged the duties of a father in his dealings with the boy willing to place himself, literally, in loco parentis when the family was still intact. ${ }^{128}$ It was thus in the court's view unconscionable ${ }^{129}$ to renounce his obligations now that he had fallen out with his wife. ${ }^{130}$ With reference to a child's right to parental care in terms of section 28(1) of the Constitution, the court intimated that the boy, having become the putative son of the defendant, had the right to expect him to provide the family and parental care that the section contemplates. ${ }^{131}$

In finding the defendant obliged to pay part of the boy's school fees, Brassey $\mathrm{J}$ did not consider it necessary to conclude that the boy was de




facto adopted, that such a relationship is or should be recognised under the operative statute, or even that the stepfather was under a general duty to maintain the boy:

"It is enough that I conclude, as I have, that the defendant held himself as SB's [the boy's] father ... To find that, in such circumstances, the defendant bears the obligation to contribute towards SB's private school tuition gives due recognition to the constitutional rights and protections to which children are entitled in terms of the clause in the Bill of Rights I have cited above. The defendant had in effect promised to do this, and the law would be blind if it could not hold him to his promise."

Brassey $\mathrm{J}$, however, indicated that were it necessary to make a finding of de facto adoption in order to conclude that the defendant is bound to look after SB, he would have little hesitation in doing so. ${ }^{133}$ Brassey $\mathrm{J}$ rejected the argument that the Flynn case was authority for the proposition that a de facto adoptive relationship enjoys no recognition in our law and thus cannot provide a basis for concluding that the adoptive parent is under a duty to support the child in question. ${ }^{134}$ The impact of the Flynn judgment was interpreted restrictively "as ultimately establishing no more than that, firstly, a de facto adoption cannot always be equated with a de jure one and, secondly, that it should not be recognised for the purposes of intestate succession". ${ }^{135}$ Brassey $\mathrm{J}$ deemed the following two factors important when considering whether to recognise a claim based on the existence of a de facto adoption: The context in which the claim was made and the practical implications of the claim. ${ }^{136}$ The court was at pains to distinguish the claim in the present case from claims considered in other contexts. The court indicated that while the factors considered in other cases were important, they could not in the instant case act as a barrier to the recognition of a claim based on a de facto adoption "when all that is at stake are the rights and obligation of putative child and father inter se". ${ }^{137}$

In $J T \vee$ Road Accident Fund ${ }^{138}$ the court was presented with a factual matrix that was deemed novel. Her grandmother formally adopted the daughter of the unmarried parents. ${ }^{139}$ The child's mother had abandoned the family and the father was often absent as a result of work commitments. ${ }^{140}$ The adoption was thus a way of providing the child with the stability of a permanent home and considered in the best interests of the child. ${ }^{141}$ The child was almost 7 years old at the time of the adoption order. ${ }^{142}$ The child's father remained in touch with her and after moving closer became very

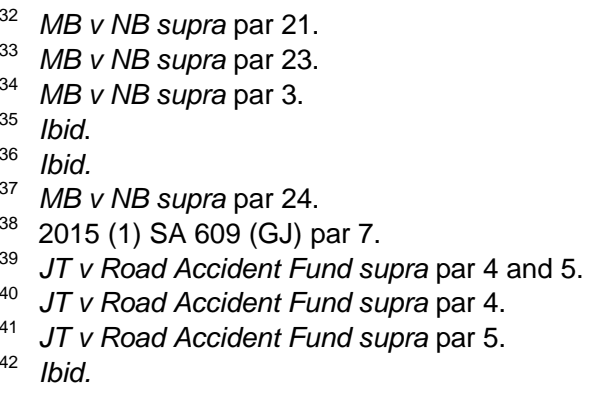


involved in her life. ${ }^{143}$ He contributed to her upkeep before and after the adoption and it was common cause that he supported her throughout. ${ }^{144}$ The father was killed in a motorcar accident in 2012 when the minor was 14 years old. ${ }^{145}$ The grandmother then instituted an action on behalf of the minor against the RAF for the loss of support resulting from the death of the father. ${ }^{146}$ The RAF denied responsibility on the ground that there was no legal duty on the father to support his daughter after she had been adopted by her grandmother. ${ }^{147}$ The question was thus whether the de facto contribution towards the child's support created a legally enforceable duty and whether the common law should be developed to provide for such a right. $^{148}$

Although the extinction of all the rights and duties of "former" parents would ordinarily be the consequence of an adoption order in terms of section $242,{ }^{149}$ the court ${ }^{150}$ deemed it important to note that the consequences mentioned in the provision have been made subject to an "introductory caveat", which allowed the Children's Court to order otherwise. ${ }^{151}$ In this regard, the court referred to the judgment in Centre for Child Law v Minister of Social Development ${ }^{152}$ emphasising the importance of the proviso to section 242 in altering the consequences of an adoption order. ${ }^{153}$ Sutherland $\mathrm{J}$ in $J T$ deduced from the Centre for Child Law judgment, first of all, that the ambit of section 242 is "overbroad" and, secondly, that the provision creates a wide scope for judicial discretion in the allocation of parental rights and responsibilities between natural or former parents and present adoptive parents in the terms of an adoption order. ${ }^{154}$ Sutherland $\mathrm{J}$ concluded that the effect of an adoption order in terms of section 242(1) -

\footnotetext{
$J T \vee$ Road Accident Fund supra par 6

Ibid.

145 JT v Road Accident Fund supra par 1.

146 Ibid.

147 JT v Road Accident Fund supra par 7
}

148 Ibid.

149 Which, as pointed out by Heaton Family 2015 (1) JQR, was not applicable to the adoption in question because the adoption order was granted before the enactment of the current Children's Act. The adoption in this case was thus still regulated by the since repealed Child Care Act 74 of 1983, that regulated the default consequences of an adoption order in far stricter terms.

150 JT v Road Accident Fund supra par 9.

151 As another example of how the ordinary consequences of an adoption order can be modified, the court also mentioned the possibility of the adoptive parents and the former parents entering into a post-adoption agreement "after the adoption" (par 9). As correctly pointed out by Heaton Family 2015 (1) JQR, the example is equally inappropriate since s 234(1) makes it clear that a post-adoption agreement must be entered into before an application for the adoption of a child is made and cannot therefore affect the consequences of the adoption ex post facto.

1522014 (1) SA 468 (GNP) par 14.

153 See discussion of Centre for Child Law v Minister of Social Development supra in 26 below.

154 JT $\vee$ Road Accident Fund supra par 12. 
"is therefore not a fixed and immutable bundle of unchangeable rights and duties but rather s 242(1) merely sets out a default position that may be varied in accordance with an order, tailored ad hoc to a specific child".

The court thus concluded that although the duty of support between parent and child, as a general rule, came to an end when the child is adopted, it was by no means necessarily the case since the court could vary the effects of the adoption in accordance with the needs of the specific child. $^{156}$ To seek support for its conclusion, the court canvassed the scope of recognition afforded to the duty of support premised on non-traditional grounds, such as parenthood and marriage. ${ }^{157}$ The court referred to two cases where the legal duty of a child to support his/her parent was recognised for purposes of a claim for loss of support arising from the death of the child. ${ }^{158}$ In Jacobs $v$ Road Accident Fund ${ }^{159}$ the court held that the voluntarily assumption of the duty by the child created a legal right for the parent and in Fosi $v$ Road Accident Fund ${ }^{160}$ the origin of the obligation was found to reside in customary law. Sutherland $J$ then considers cases in which a duty of support between life-partners outside marriage was recognised. ${ }^{161}$ With reference to the judgment in Paixao $v R A F^{162}$ attention is drawn to Cachalia J's pronouncement that in determining whether the claimant's right is worthy of protection, reference must be made to the morality of society, which is divined by an exercise of judicial policy-making aimed at acknowledging that social changes warrant "legal norms to encourage social responsibility". ${ }^{163}$ In this regard, reference is also made to the Metiso and MB cases, discussed above. Based on these precedents Sutherland concludes:

"It seems to me that these cases demonstrate that the common law has been developed to recognise that a duty of support can arise, in a given case, from the fact-specific circumstances of a proven relationship from which it is shown that a binding duty of support was assumed by one person in favour of another. Moreover, a culturally imbedded notion of 'family', constituted as being a network of relationships of reciprocal nurture and support, informs the common law's appetite to embrace, as worthy of protection, the assumption of duties of support and the reciprocal right to claim support, by persons who are in relationships akin to that of a family. This norm is not parochial but rather is likely to be universal, it certainly is consonant both with norms derived from the Roman-Dutch tradition, as alluded to by Cachalia JA in Paixao $v R A F$ supra and, no less, from norms derived from African tradition, not least of all as exemplified by the spirit of Ubuntu, as mentioned by Dlodlo $\mathrm{J}$ in Fosi $v$ RAF supra."

155 Ibid. However, even if s 242 was applicable (which it was not), the order itself would have had to vary the default consequences of the adoption order - which the adoption order in this case did not do. The court cannot change the default consequences of the order on an ex post facto basis.

156 JT v Road Accident Fund supra par 12.

157 JT $v$ Road Accident Fund supra par 14.

158 JT $v$ Road Accident Fund supra par 15-17.

1592010 (3) SA 263 (SE).

1602008 (3) SA 560 (C).

161 JT v Road Accident Fund supra par 19, 21 and 23.

1622012 (6) SA 377 (SCA).

163 JT v Road Accident Fund supra par 13.

164 JT v Road Accident Fund supra par 26. 
And later:

"A duty of support between de facto family members is one of those areas in which the law gives expression to the moral views of society. The common law ought to be developed to embrace this norm and the order in this matter serves to do so."

\section{Recognition of de facto adoption in baby-swop case}

The possibility of attributing legal consequences to a de facto caregiving relationship was also considered recently in the baby-swop case of Centre for Child Law $v$ NN and NS. ${ }^{166}$ While full reasons for the judgment have not been handed down, it is clear from the order that the court, for the most part, accepted the recommendations made by the curator ad litem, appointed for the two children in the case. ${ }^{167}$ Based on the expert reports by the psychologists and psychiatrist, the curator argued that the relationship that had developed between the putative parents and their unrelated children should be regarded as de facto adoptions that should be legally recognised as formal adoptions in this case. ${ }^{168}$ The curator reasoned that, unlike a parental responsibilities and rights order, adoption had lifelong consequences that "would solve all the legal problems including those relating to succession". ${ }^{169}$ However, the curator did not consider it advisable to require the putative parents to follow the ordinary prescribed procedure to obtain a formal adoption order. ${ }^{170}$ It would, in the curator's opinion have necessitated the de facto parents going through "the laborious children's court process of adopting a child they already consider to be their own", an option that in the curator's opinion "would be an affront to their dignity and might place the best interests of each child at risk". ${ }^{171}$ Furthermore, there was a possibility that the children would not even qualify as "adoptable" within the meaning of the concept as defined in the Children's Act. ${ }^{172}$ To determine whether the situation in which the parents and children in this matter found themselves could be regarded as de facto adoptions, the curator referred to case law illustrating that such adoptions have been recognised in our law. ${ }^{173}$ Where such recognition was not granted, the report contends, the denial was limited to the context of intestate succession. ${ }^{174}$ The curator regarded the recognition of customary law adoptions relevant for two reasons: Firstly, they confirm that adoptions not formalised in

165 JT $v$ Road Accident Fund supra par 30. The same conclusion was reached in ZMM v RAF GSJ (unreported) 2015-08-20 Case no 35933/2012 par 13.

166 GSJ (unreported) 2015-11-16 Case no 32053/2014.

167 See Venter "Court rules in baby-swop case" 2015-11-17 IOL http://www.iol.co.za/news/ crime-courts/court-rules-in-baby-swop-case-1946432 (accessed 2016-04-27).

168 See par 145 of the Report of the Curator ad litem dated 2015-11-25.

169 Report of the Curator ad litem par 129.

170 Report of the Curator ad litem par 133.

171 Report of the Curator ad litem par 129.

172 Report of the Curator ad litem par 130-132.

173 Report of the Curator ad litem par 142

174 Report of the Curator ad litem par 135-140. 
accordance with the prescribed formalities expressed in legislation can be recognised in our law; Secondly, it suggests that it is possible to effect an adoption at customary law through the performance of certain rites and rituals. ${ }^{175}$ This, the curator argues -

"might be a mechanism through which one could ameliorate any customary

law disputes that might arise in this case because the children do not having

[sic] a biological link to their caregivers. It might be a way in which to appease

any uneasiness felt by the families of the children concerned and a way to

'make things right' from a religious and cultural perspective."

With reference to the Maneli case, the curator furthermore stated that nothing in the Children's Act precludes the recognition of de facto adoptions. ${ }^{177}$ Finally, to amplify the applicability of the concept of de facto adoption in the context of babies who are switched at birth, the curator referred ${ }^{178}$ to the concept of "equitable adoption" in the USA and to the following passage from Foote, ${ }^{179}$ an American author:

"If a person is willing to assume responsibility for support of a child and wants to be recognised as the parent, then under certain circumstances that person may be considered a parent who is entitled to receive custody or visitation rights. The alternative of equitable adoption gives both parents an equal chance to gain custody of the child and allows for a compromise of joint custody of the children. Equitable adoption provides the psychological parent an opportunity to act as an equitably adoptive parent. Using the theory of equitable adoption gives both the biological and psychological parents an equal chance to seek custody and visitation rights. Putting them on equal footing allows the court to bypass all of the parental rights problems and go straight to the [pertinent] issue: the best interests of the child. If this can be achieved by recognising custody and visitation rights in both sets of 'parents,' similar to that which results after a divorce when parents remarry, then the court should do so to allow both families to cooperatively raise the child."

Despite the "extraordinary circumstances" of the case making the application of general principles difficult, the curator seemed to consider it prudent to construe the relationships that had developed between the putative parents and children as de facto adoptions. ${ }^{181}$ Based on the best interests of the children it was recommended that the court retrospectively validate the de facto adoptions as if the biological parents at birth had formally adopted the swopped child they had bonded with. ${ }^{182}$ To recognise the relationships as formal adoptions would in the curator's opinion also bring the legal relationship between the de facto parents and their children in line with what the birth registration details and birth certificates depict. ${ }^{18}$

\footnotetext{
175 Report of the Curator ad litem par 143.

176 Ibid.

177 Report of the Curator ad litem par 142

178 Report of the Curator ad litem par 144.

179 Mistakenly referred to as "Foot" in par 145 of Report of the Curator ad litem.

180 See Foote 1999-2000 21 Whittier LR 338.

181 Report of the Curator ad litem par 145.

182 Ibid.

183 Report of the Curator ad litem par 148-149.
} 
Presumably persuaded by these arguments, the court ordered the retention of the status quo. In terms of the order, the unrelated mothers and their partners acquire full parental responsibilities and rights in respect the children they had raised as their own "with retrospective and prospective effect through the operation of the principle of de facto adoption". ${ }^{184}$ All parental responsibilities and rights are to be applied as if they are the adoptive parents of the children. ${ }^{185}$ As recommended by the curator, the court simultaneously terminated the parental responsibilities and rights automatically acquired by the biological mothers in respect of their biological children at birth. ${ }^{86}$ The children would continue to have contact with their biological parents. ${ }^{187} \mathrm{~A}$ parenting coordinator, appointed in terms of the directions contained in the order, will manage the exercise of contact. ${ }^{188}$ The therapeutic support and integration services provided by the Child and Adolescent Family Unit are to continue until the parties agree that the service is no longer required.

\section{Other recognition of de facto adoptions}

While not strictly speaking examples of circumstances in which a de facto adoption was recognised, the following cases do show an increased willingness on the part of the courts to interpret the statutory provisions relating to adoption liberally to accommodate the best interests of the child. In $R e X N,{ }^{190}$ the court condoned non-compliance with a statutory requirement in the following rather revealing terms:

"However, although the best interests of the child cannot be sacrificed at the altar of formalism, if the requirement of $s 239(1)(d)$ is not complied with, the objectives of the Children's Act will be lost. The children's courts are charged with overseeing the well-being of children, examining the qualifications of applicants for adoption and granting adoption orders. To carry out their functions effectively and conscientiously they rely on the efficient collaboration of all stakeholders, the department and social workers to comply with their respective obligations in terms of the Act. Non-compliance with the provisions of the Act will delay the speedy facilitation of adoption applications, bringing the administrative processes to a halt, if not into disrepute. It should be a concern when those who are empowered by legislation to fulfil their functions appear recalcitrant, especially in matters involving the vulnerable members of our society. Nevertheless, in my view, this does not give the child commissioner carte blanche to condone non-compliance with the provisions of the Act. This can only be done if the circumstances are exceptional and warrant it, as in this case."

Despite the ostensible closed list of children who would be deemed adoptable in terms of section 230(3) of the Children's Act, the court in Centre

\footnotetext{
184 Centre for Child Law $v$ NN and NS supra par 1, 2, 7 and 8.

185 Ibid.

186 Centre for Child Law $v$ NN and NS supra par 3 and 9.

187 Centre for Child Law $v$ NN and NS supra par 5, 6, 11 and 12.

188 Centre for Child Law $v$ NN and NS supra par 13 read with par 15.

189 Centre for Child Law $v$ NN and NS supra par 14.

1902013 (6) SA 153 (GSJ) par 19.
} 
for Child Law v Minister of Social Development ${ }^{191}$ held that the definition does not preclude a child from being adoptable in instances where the child has a guardian and the person seeking to adopt the child is the spouse or permanent domestic life partner of that guardian. By regarding a stepchild as being abandoned by one of his or her parents and therefore qualifying as adoptable in terms of the provision, the court found it unnecessary to consider the provision's constitutionality. ${ }^{192}$ The court also held, as mentioned above, that despite the fact that the wording of section 242 may suggest otherwise, an adoption order does not automatically terminate all the parental responsibilities and rights of the guardian of a child when an adoption order is granted in favour of the spouse or permanent domestic life partner of that guardian. ${ }^{193}$ The court came to this conclusion based on the proviso in the section in terms of which a court could change the default effect of the adoption order by providing "otherwise". ${ }^{194}$ In this way, an inquiry into the constitutionality of section 242 was also not deemed necessary.

In $G T \vee C T^{196}$ the court was willing to set aside an adoption order granted in favour of the applicant after a lapse of 6 years from the date of the order, ${ }^{197}$ notwithstanding the maximum expiry period of two years for the application set in terms of s 243(2) of the Children's Act. ${ }^{198}$ The stepfather had adopted the children a year after marrying their mother, who was divorced from the children's biological father. ${ }^{199}$ However, after their divorce, the mother had refused to allow the stepfather to exercise his parental rights while still expected him to maintain the children. ${ }^{200}$ The children had continued to regard their biological father as their father. The stepfather applied for the rescission of the adoption order, arguing that it would be in the best interests of the children to allow their biological parents to

\footnotetext{
2014 (1) SA 468 (GNP) par 13.

Centre for Child Law v Minister of Social Development supra par 15.

Centre for Child Law v Minister of Social Development supra par 17.

Centre for Child Law v Minister of Social Development supra par 14.

Centre for Child Law v Minister of Social Development supra par 15.

[2015] 3 All SA 631 (GJ) par 62.

GT v CT supra par 19.

198 Under the previous Child Care Act 74 of 1983, several provisions were found unconstitutional, inter alia, for not being in a child's best interest. In Fraser $v$ Children's Court, Pretoria North 1997 (2) SA 261 (CC), the Constitutional Court declared the consent provision contained in $s$ 18(4)(d) unconstitutional for not affording at least a committed father the opportunity to object to the adoption of his child born out of wedlock. The citizen requirement in terms of $\mathrm{s} 18(3)(\mathrm{f})$ of Child Care Act was abolished in Minister of Welfare and Population Development v Fitzpatrick 2000 (3) SA 422 (CC) and in Du Toit v Minister of Welfare and Population Development (Lesbian and Gay Equality Project as Amicus Curiae) 2003 (2) SA 198 (CC) the Constitutional Court ordered s 18 to be read in so as to allow same-sex life-partners the right to apply jointly for the adoption of a child. In $T \vee C 2003$ (2) SA 298 (W) as well as AS v Vorster 2009 (4) SA 108 (SE), the High Court refused to rescind the adoption orders granted in these cases based on the best interests of the adopted children in question. The courts denied the request for rescission despite the fact that the required parental consent was not obtained for the adoption and a ground for the rescission therefore existed in terms of s 21(1)(a) of the said Act.

199 GT V CT supra par 20.

200 GT V CT supra par 29 and 30.
} 
(re)assume their role as lawful parents. ${ }^{201}$ The court rescinded what it considered the fiction of the de jure adoption in order to "formalise the de facto family unit existing between the children and their biological parents". 202

\section{DOCTRINE OF EQUITABLE ADOPTION IN USA}

A brief discussion of the doctrine of equitable adoption applied in the USA is deemed necessary to supplement the anecdotal nature of the information provided in the Flynn and Centre for Child Law cases.

Several states in the USA ${ }^{203}$ have recognised that statutory adoption is not the sole means of adoption. ${ }^{204}$ The doctrine of equitable adoption, also called "adoption by estoppel", "virtual adoption" or "de facto adoption", has on occasion been invoked to recognise a child as the adopted child of a nonbiological parent even when there has been no statutory adoption. ${ }^{205}$ Baunach explains:

"The doctrine applies when a legally competent person enters into a binding legal contract to adopt a child, but the performance falls short of statutory adoption. Courts of various states utilize the doctrine in cases ranging from enforcing child support to contesting a will. The main thrust of the doctrine is that although there is no completed statutory adoption, the best interests of the child demand that the court impose an adoption by estoppels."

According to Baunach, ${ }^{207}$ the application of the doctrine in the USA originally turned on the existence of two elements: circumstances evidencing a parent-child relationship and the existence of a contract to adopt. ${ }^{208}$

201 GT V CT supra par 31

${ }^{202}$ GT v CT supra par 61. For criticism of the judgment, see Sonnekus "Kinderaanneming dra Gevolge wat nie Ligtelik Afgelê kan word nie" 2015 TSAR 886.

203 According to Knaplund "Grandparents Raising Grandchildren and the Implications for Inheritance" 200648 Arizona $L R 16$, at least 28 states recognise equitable adoption, which means that the doctrine is a theoretical option in the majority of states.

204 Baunach 1992-1993 31 University of Louisville Journal of Family Law 503.

205 See eg, Rein "Relatives by Blood, Adoption, and Association: Who Should Get What and Why (The Impact of Adoptions, Adult Adoptions, and Equitable Adoptions on Intestate Succession and Class Gifts)" 198437 Vanderbilt LR 711; Baunach 1992-1993 31 University of Louisville Journal of Family Law 501; Yount "Lankford v Wright: Recognizing Equitable Adoption in North Carolina" 1997-1998 76 North Carolina LR 2331; Robinson 199948 Emory LJ 943; Foote "What's Best for Babies Switched at Birth? The Role of the Court, Rights of Non-biological Parents, and Mandatory Mediation of the Custodial Agreements" 1999-2000 21 Whittier LR 315; Warner "Bending the Bow of Equity: Three Ways Florida can Improve its Equitable Adoption Policy" 2008-2009 38 Stetson LR 577 Johnson "A Suggested Solution to the Problem of Intestate Succession in Non-traditional Family Arrangements - Taking the 'Adoption' (and the inequity) out of the Doctrine of 'Equitable Adoption'” 1 March 2009 http://ssrn.com/abstract=1512815 or http://dx.doi.org/10. 2139/ssrn.1512815; Wright "Inheritance Equity: Reforming the Inheritance Penalties Facing Children in Non-traditional Families" 201525 Cornell Journal of Law \& Public Policy 1.

206 Baunach 1992-1993 31 University of Louisville Journal of Family Law 503.

207 lbid.

208 See also Robinson 199948 Emory LJ 955 and Warner 2008-2009 Stetson LR 589-590. 
Because estoppel is an equitable tool of the court, ${ }^{209}$ used only when a party has relied on the promise of another to his or her detriment, the courts created the contract to adopt a requirement to portray reliance justifying estoppel. ${ }^{210}$ However, the problem was that adoption by estoppel situations did not always lend themselves to such a cut-and-dried requirement. ${ }^{211}$ As the courts tried to meet the demands of equity regarding a child's best interest in situations such as baby switch cases, the contract requirement was diluted. ${ }^{212}$ Not only was it no longer required that the biological parent be a party to the contract, it did not matter with whom the contract was made, as long as it was for the child's benefit. ${ }^{213}$ Ultimately, some states now only require proof of a real parent-child relationship. ${ }^{214}$ According to Wright, ${ }^{215}$ equitable adoption is a rarely invoked doctrine and is even more rarely applied. A study of the most recent thirty USA appellate level cases involving equitable adoption since 1987 conducted by Wright has revealed that only six affirmed the inheritance rights by finding that the child should be treated as having been equitably adopted. ${ }^{216}$ The basis and scope of the recognition and application of the doctrine of equitable adoption in the USA have clearly remained uncertain and contentious.

It is perhaps ironic that while equitable adoption in the USA is most commonly applied and limited to establish a right to intestate succession for a child, ${ }^{217}$ this has been one of the few situations in which the South African courts have refused to recognise a de facto adoption.

\section{CREATION OF A DOCTRINE OF DE FACTO ADOPTION IN SOUTH AFRICA}

As far as a doctrine of de facto adoption is to be gleaned from the cases discussed in paragraph 2, a careful distinction should be made between the different contexts within which the cases were decided. First of all, it would seem unnecessary to recognise or apply the doctrine in the context of customary law adoptions. While customary law adoptions are arranged and completed extra-judiciously and could thus broadly be termed "informal", these adoptions fall in a class of their own. Customary law, like the common law, forms an integral part of our law. Section 211(3) of the Constitution

209 While equity has its origins in English law, there is nothing to suggest that consideration has been given to the concept of equitable adoption and the recognition of informal adoptions in the UK. However, a so-called "adoption concession" operates in the UK for immigration purposes which reflects a process where adoptive parents are not restricted to parents who have adopted a child through a process that was legally recognised under UK law: See Cohen Immigration Controls, the Family and the Welfare State (2001) 92.

210 Baunach 1992-1993 31 University of Louisville Journal of Family Law 503.

211 Baunach 1992-1993 31 University of Louisville Journal of Family Law 503; Robinson 1999 48 Emory LJ 958.

212 Baunach 1992-1993 31 University of Louisville Journal of Family Law 503.

213 lbid.

214 Ibid.

215 Wright 201525 Cornell Journal of Law \& Public Policy 47.

216 Ibid.

217 See Robinson 199948 Emory LJ 962 . Florida is one example of a state where the doctrine is only applied in this context: See Warner 2008-2009 Stetson LR 588. 
obliges courts to apply customary law when applicable, provided it is not in conflict with the Constitution, or any legislation specifically dealing with customary law. It is evident from the courts' pronouncements in this regard that the practice of adoption as determined by customary law is in harmony with the Constitution. Such adoptions are recognised as a natural extension of the constitutional right to culture, non-discrimination and the paramountcy of the best interests of the child. There seems to be little doubt after the judgment in Maneli that adoption in terms of customary law has become an alternative route to acquiring full parental status. The amended definition of "descendant" has settled the uncertainty in the customary law of succession and the allusion to "any law" in the definitional section in the Children's Act should suffice for all other purposes. To dispel any remaining doubts in this regard, it may nevertheless be advisable to amend the definitions of "adopted child" and "adoptive parent" in the Children's Act to give express statutory recognition to customary law adoptions. However, because there is no uniform adoption procedure in terms of customary law, a court order may still be required to scrutinise adherence to the applicable customs before endowing the adoptive parents with parental status. Despite the need for judicial confirmation, customary law adoptions are therefore not typical informal adoptions. Customary law adoptions are recognised in terms of a separate legal system ${ }^{218}$ on a dual basis with formal adoptions. ${ }^{219}$ I would, therefore, argue that even if a doctrine of de facto adoption is recognised in South Africa it can or should find no application in the context of customary law.

The judicial recognition of de facto adoptions in one baby-swop case can in my view also not set a strong enough precedent to accept it as a point of departure in all baby-swop cases, however, rarely they may occur. ${ }^{220}$ The circumstances in these cases are far too diverse and complex to resolve with the application of general principles or doctrines. While retaining the status quo in baby-swop cases would naturally seem alluring amidst the shock and devastating effect of being informed of the swop, it may not necessarily be the best solution in all cases. Reconstructing the relationships that had developed between the parents and their swopped babies as de facto adoptions, in any event, seemed rather contrived. Moreover, even in the Centre for Child Law case the court's decision to permanently sever the bonds between the biological parents and their natural children, in my opinion, can be questioned. It would on the face of it seem a particularly inappropriate step given the uncertainty that arises in the aftermath of a baby-swop. I am not suggesting a summary return of the child to the biological parents. The Children's Act has created the possibility of multiple

218 Maithufi "Metiso $v$ Road Accident Fund case no 44588/2000 (T): Adoption according to Customary Law" 200134 De Jure 390397.

219 Ferreira Interracial and Intercultural Adoption 375. The same dual recognition of customary law adoption is found in Botswana (see Ferreira Interracial and Intercultural Adoption 8) and aboriginal customary adoption in Canada: See Baldassi "The Legal Status of Aboriginal Customary Adoption across Canada: Comparisons, Contrasts and Convergences" 200639 University of British Colombia LR 63.

220 According to a study in the USA the chance of babies being switched at birth is $0.1 \%$ : See Foote 1999-2000 21 Whittier LR 315-16. 
co-holders of parental responsibilities and rights. ${ }^{221}$ The Act has also given some guidance on how to regulate the co-exercise of these responsibilities and rights. ${ }^{222}$ The South African Children's Act has provided enough flexibility in the assignment of parental responsibilities to make it unnecessary to use the concept of equitable adoption or any related doctrine of de facto adoption to deal with the problems that arise in these cases. According to Baunach and Foote, the doctrine of equitable (or de facto) adoption is helpful in these situations because it could effectively give the children two sets of parents who can then on an equal basis argue for care and contact based on the child's best interests. ${ }^{223}$ According to these authors, the application of the doctrine in baby-swop cases could thus be used to give the unrelated putative parents an equal standing to the biological parents in care and contact determinations and facilitate mediation, perhaps for joint custody arrangements. ${ }^{224}$ Using the doctrine to facilitate the termination of the rights that the biological parents had automatically acquired at birth would thus not seem to have been contemplated.

Customary law adoptions and baby-swop cases should, therefore, in my opinion, fall outside the scope of application of any devised or imputed doctrine of de facto adoption. The only contexts left to consider are the child support context and the intestate succession context. If regard is had to the cases discussed in paragraph 24 above, an informal or de facto care arrangement that resembles an adoptive relationship has without exception been recognised for purposes of creating a duty of support between the child and the putative parent. The courts have in fact been willing to impute such a duty merely from a binding assumption of a duty to support, regardless of whether the relationship resembled an adoptive relationship, moving from a rationale of best interests and the right to parental care to the moral views of society.

In the single judgment in which the issue was considered, the court was not prepared to equate the positions of a de jure and a de facto adopted child for purposes of creating a right to intestate succession. However, the ratio in the Flynn case bears further reflection. First of all, the court could not resort to either the right to parental care or the best interests standard since the "child/dependant" in question was a (deceased) adult at the time of institution of the proceedings. The South African equivalent of the "equitable" rationale for recognising the relationship as an adoption thus had to be found on the constitutional rights to equality and non-discrimination, or fail. The analogy drawn in Flynn between spouses married in terms of religious law, unmarried cohabitants and a de facto adoption is highly instructive. The constitutional right to religion and culture and "common sense and justice" have provided the justification for the judicial recognition of religious spouses

\footnotetext{
Ss $18(4)$ and $30(1)$.

Ss $30,31,33$ and 35

223 Baunach 1992-1993 31 University of Louisville Journal of Family Law 512; Foote 1999200021 Whittier LR 338.

224 Baunach 1992-1993 31 University of Louisville Journal of Family Law 512; Foote 1999200021 Whittier LR 338.
} 
and customary law adopted children on a par with formally married spouses and formally adopted children. Beyond the realms of religion and culture, there was also justification in the past to treat unmarried life-partners of the same sex as spouses because they were barred from getting married. Since heterosexual life-partners have the choice to get married they were not afforded the same recognition in terms of the Volks judgment. The court in Flynn used the Volks judgment to support its conclusion that the differentiation between de facto adopted children and formally adopted children does not amount to unfair discrimination. However, to equate the decision to get married with the decision to adopt is to ignore the fact that an adoption may depend on the decision of individuals other than the adoptive parents, i.e. the biological parents of the child to be adopted. If the biological parents of the child refuse to consent to the adoption, the adoption will be thwarted, regardless of how badly the adoptive parents want to adopt the child. What is more, the child cannot choose to be adopted. The decision is entirely in the hand of the adults who are involved. Only when the adoptive parents decide to adopt and the biological parents give their consent, are the wishes of the child, if old enough, taken into consideration. The reasons why Farr never adopted Flynn were not canvassed in any detail. If Farr was barred from adopting Flynn because Flynn's biological father refused to consent to the adoption as was suggested, then surely Flynn cannot be prejudiced for a decision that was not his to take? Based on this reasoning the position of Flynn and Farr bears far more resemblance to the position of same-sex life-partners before the enactment of the Civil Union Act ${ }^{225}$ than the position of heterosexual couples. The use of the so-called "choice argument" in the case of adoption is, therefore, in my opinion, even more, illusory than in the case of unmarried life-partners. ${ }^{226}$ It should thus be the nature of the putative parent-child relationship that should decide whether de facto adopted children should be treated as having been formally adopted. The current trend in familial proceedings, favouring the recognition of substance or function rather than legal status or form, would support such an approach. ${ }^{227}$ The crucially important pursuit of substantial equality was not mentioned in the Flynn case. Apart from the need to treat similarly situated individuals equally, Brassey $\mathrm{J}$ in $M B$ emphasised the importance of the context in which the claim for recognition was made and the practical implications of the claim. ${ }^{228}$ The factual scenario in the Flynn case in my view provided ample opportunity for the court to apply the doctrine of equitable adoption in its originally intended sense. ${ }^{229}$ Perhaps if it had been "cogently argued" the outcome of the case may have been different on the basis that the application of the doctrine does not advocate the recognition

17 of 2006.

226 Simply put, the choice argument dictates that unmarried partners cannot claim spousal benefits because they choose not to marry. For a further analysis and criticism of this argument, see Bester and Louw "Domestic Partners and 'The Choice Argument': Quo Vadis?" 201518 PER 2951 2953-2957.

227 See Schwenzer 200711 Electronic Journal of Comparative Law 2.

${ }^{228} M B \vee N B$ supra par 3.

229 Robinson 199948 Emory LJ 990 proposes that claims for inheritance should be evaluated not only on the bare facts of biology and formal adoption but also on the basis of what might, according to him, be called more "elective affinities". 
of all de facto adoptions. The application of the doctrine depends on the factual circumstances on a case to case basis, similar to any equitable determination such as a best interests determination in relation to a child.

\section{CONCLUSION}

It should be evident from the above exposition that South African courts have consistently recognised a de facto adoption for purposes of the recognition of a duty of support between the child and the putative parent. A doctrine of de facto adoption has thus evidently emerged in this context. Equity in this context can be justified by the child's constitutional rights to parental care and best interests encapsulated in section 28. Despite the Flynn judgment, the possible application of the doctrine to create a right of intestate succession should, in my view, not be rejected outright. In this context, the element of equity could be justified by the constitutional right to (substantial) equality depending on the particular circumstances of each case. If the doctrine of de facto adoption can be applied in both these contexts, it would mean that the law would allow for the recognition of de facto adoptions in all cases concerned with so-called "need-based" claims also proposed elsewhere in relation to domestic partners. ${ }^{230}$ De facto adoption should not be made the equivalent of statutory adoption. ${ }^{231}$ The application of the doctrine should be limited to the contexts of support and intestate succession. The limited application of the de facto adoption doctrine would ensure that the protection of the children for whom the adoption statute was actually intended, will not be eroded. ${ }^{232}$ The limited application of the doctrine will in this way uphold the integrity of the formal adoption process in South Africa ${ }^{233}$ while at the same time ensure equitable results in meritorious recognition of de facto adoption cases.

230 See Bester and Louw 201518 PER 2959-2961 and 2968-2969.

231 See Rein 198437 Vanderbilt LR 810.

232 Rein 198437 Vanderbilt $L R 810$ argues that sympathies for the equitably adopted child "cannot be indulged without threatening the fabric of our adoption procedures and thus sacrificing the larger good of ensuring suitable placement for all children to the exigencies of the particular case".

233 As argued for by DSD in the Flynn case. 